\section{APP-69 山口県東部地域における前立腺癌の疫 学調查}

国立岩国病院 泌尿器科、山口県東部污尿器科研究会 別宮 謙介, 三宅 知子, 小武家 誠, 宮地 禎幸 【目的】山口県東部地域における前立腺癌の発生頻度を正 確に把握し、将来的に日本人の泌尿器癌の発生頻度を推 計するために行った。対象及び方法】対象は山口県東部 地域において 1994 年から 2001 年までの過去 8 年間に新 たに前立腺癌と確定診断された未治療症例である。对象 地域は山口県東部の山口市、徳山市、岩国市等を中心と した 8 市 7 群であり、総人口は 847,561 人で、その内男性 人口は 403,025 人（2000 年 10 月 1 日現在）であった。方 法は山口県東部地域の泌尿器科専門医のいる医療施設を 中心に、同地域を全て網羅するために泌尿器科専門医の いない医療施設にも調査を依頼し、毎年 1 月から 12 月ま でに前述の各医療施設で確定診断された症例の届け出方 式とした。結果】末治療前立腺癌と診断された症例は 1994 年は 99 例、1995 年は 132 例、1996 年は 155 例、 1997 年は 152 例、1998 年は 196 例、1999 年は 226 例、2000 年は 230 例と年々増加傾向を認め、世界人口を基準とし た年齡調整䍜患率も 1994 年の 10.57 から $13.42 、 15.10$ 、 14.38、18.80、19.93、20.70 と增加傾向を認めた。今までの国 内の報告に比べ高值であり、過去 8 年間の調査結果より 本地域における前立腺癌の発生頻度について検討した。

\section{APP-70 PSA 正常BPH 群 と gray zone BPH 群 における内腺および外眿の PSA 分泌量 と density 計測の試み}

\section{日本医科大学付属多摩永山病院泌尿器科}

平岡 保紀, 左 維, 阿部 裕行, 高橋 洋文, 清水 有二 岩本 和矢, 沼沢 和夫, 藤田 和明, 伊藤 博, 服部智任 【目的】:PSA 正常 BPH 群と PSA gray zoneBPH群に对し て、内腺と外腺の PSA 分泌量、PSAD、PSAD-TZ、内腺およ び外腺の PSADについて検討した。。【対象および方法】：1999 から 2001 年まで当科において PSA 正常 BPH群 102 例と PSA gray zoneBPH 群 59 例を対象として TUEを施行し、術 前と術後 6 ヶ月頃にPSA 測定およびTRUS で前立腺の体積 を測定して、内腺および外腺の PSA 分泌量と各種 PSA density 值を算出した。。【結果】：PSA 正常 BPH 群と gray zone BPH 群二群間の PSA 総分泌量はそれぞれ 1.8 と $6.1 \mathrm{ng} / \mathrm{ml}$ で あった。2 群間の外腺 PSA 分泌量はそれぞれ 0.6 と $0.8 \mathrm{ng} / \mathrm{ml}$ 、 density は 0.07 と $0.08 \mathrm{ng} / \mathrm{ml} / \mathrm{cm} 3$ であった。2 群間の内腺 PSA 分泌量はそれぞれ 1.3 と $5.4 \mathrm{ng} / \mathrm{ml}$ 、 density は 0.11 と $0.30 \mathrm{ng} /$ $\mathrm{ml} / \mathrm{cm} 3$ であった。PSAD、PSAD-TZ、PSAD-IG、PSAD-EG 值については gray zone BPH 群が PSA 正常 BPH 群よりそれ ぞれ 2.43、2.13、2.73、1.14 倍高かった。。結論】：PSA 分泌量が 上昇する gray zone BPH 症例は外腺からの分泌量の增加は少 なく、主に内腺から PSA の分泌が六進していることが示㖫さ れた。今後、内腺と外腺からのPSA 分泌量および densityを求 めることは臨床的にも意義があると思われる。

\section{APP-71 ハンドアシストによる後腹膜鏡下腎尿 管全摘術の检討}

\begin{abstract}
佐賀医科大学 泌尿器科”国立病院九州医療センター2) 魚住 二郎", 井口 厚司 ${ }^{21}$, 藤山千里", 坂本 直孝" 明利 浩行"), 西村 和重", 狩野 武洋 ${ }^{1}$, 塚原 常宏” 中島 啓二i", 南里 正晴", 真䗁 善二郎"

【目的】上部尿路腫瘍に対するハンドアシスト後腹膜鏡下腎尿管 全摘術の有用性を検討した。㳔象と方法】1999年8月から 2002 年 8 月までに T1-2N0M0の腎昷尿管腫瘍 27 例に对して上記手 術を施行した。平均年踰 72 歳、尿管腫瘍 17 例、腎盖腫瘍 10 例 であった。下腹部正中切開にて尿管を同定して中枢㑡に向かって 剥離し、後腹膜腔を用手的に剥離应張した。次に後腹膜控にポー トを挿入し、下腹部正中創からのハンドアシストによる後腹膜鏡 下腎摘を行った。術者は 2 本の鈿子を操作し、助手が手を挿入し た。下腹部正中創からの開放手術として下部尿管摘除および膀胱 部分切除を行った。広範な皮下気腫による開放手術への移行 1 例 を除いた 26 例の解析を行った。従来の開放手術 16 例との比較検 討も行った。結果】平均手術時間は $363 \pm 110$ 分、経口摄取開始、 歩行開始はそれぞれ $1.3 \pm 0.5$ 日、2.3 00.6 日であった。開放手術と 比較して手術時間は長かったが、経口攝取開始までの時間は䂑 かった。合併症として、皮下気腫 1 例、腎静脈損傷 1 例、肺塞栓 1 例、創感染 3 例がみられた。結論】本術式は、手術時間の短縮、 合併症の予防等の課題があるが、下腹部正中創をハンドアシスト における手の挿入口、下部尿管摘除の手術創、遊離組織の摘出 ルートとして用いる合理的な術式である。
\end{abstract}

\section{APP-72 後腹膜鏡下腎腫瘍摘出術 HALS vs pure laparo}

\author{
京都府立医科大学 泌尿器科”济生会吹田病院2) 近江 \\ 八幡市民病院3) 第二岡本総合病院 ${ }^{4}$ 社会保険京都病院 ${ }^{51}$ \\ 藤戸 章", 河内 明宏"), 中尾 昌宏", 水谷 陽一" \\ 浮村 理", そう 仁哲"), 沖原宏治", 野本 剛史"

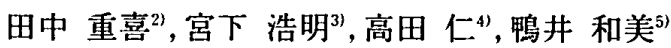 \\ 三木 恒治"
}

【目的】我々は、1999年11月よりハンドアシストを用いた後腹膜鏡下䁂 腫場摘出術 (HALS) を施行し、2001 年5月より pure laparoによる後腹 膜鏡下腎腫瘍摘出術を施行した。今回、これらの術式を比較検討したので 報告する。(方法]HALSは、腾上縁より下方に傍腹直筋切開にて後腹膜腔 に至り康管を結紮切断後、Lap-Disk を装着した。12mm ポートを3本設 置し、腎動静脈をクリップおよびEndo-GIA にて処理摘出した。瞌器は、 intact specimen で Lap-Diskより摘出した。Pure laparo は、12mm ポート を 3 本と $5 \mathrm{~mm}$ ポートを1〜2本設置し鏡視下にHALSと同様の手技に て処理摘出した。滕器は、第一ポート切開延長し intact specimen で摘出 した。手衍は、鏡視下手術開始時より担当した 2 名の医師が執刀した腫場 径 $5 \mathrm{~cm}$ 以下の庭例のみを対象とした。症例数は、HALSが 34 例、 pure laparoが 10 例であった。成績)平均手術時間は、HALSが198分、pure laparoが 229 分であった。出血量は、HALSが 168ml、pure laparoが 127 mlであった。合併症は、HALSで血腫を 1例、pure laparoで出血のため HALSへ移行した症洌を1湖認めた。結論】手術時間ではHALSが短 く、出血量では pure laparoが少ない㑯向は見られたが両者に大きな差は 認めなかった。また、QOLについても検討したので報告する。 